ARTICLE

DOI: $10.1057 /$ s41599-018-0176-7

\title{
Using evidence to influence policy: Oxfam's experience
}

Ruth Mayne ${ }^{1}$, Duncan Green ${ }^{2}$, Irene Guijt ${ }^{3}$, Martin Walsh ${ }^{4}$, Richard English ${ }^{5} \&$ Paul Cairney ${ }^{6}$

\begin{abstract}
Policymaking is rarely 'evidence-based'. Rather, policy can only be strongly evidence-informed if its advocates act effectively. Policy theories suggest that they can do so by learning the rules of political systems, and by forming relationships and networks with key actors to build up enough knowledge of their environment and trust from their audience. This knowledge allows them to craft effective influencing strategies, such as to tell a persuasive and timely story about an urgent policy problem and its most feasible solution. Empirical case studies help explain when, how, and why such strategies work in context. If analysed carefully, they can provide transferable lessons for researchers and advocates that are seeking to inform or influence policymaking. Oxfam Great Britain has become an experienced and effective advocate of evidence-informed policy change, offering lessons for building effective action. In this article, we combine insights from policy studies with specific case studies of Oxfam campaigns to describe four ways to promote the uptake of research evidence in policy: (1) learn how policymaking works, (2) design evidence to maximise its influence on specific audiences, (3) design and use additional influencing strategies such as insider persuasion or outsider pressure, and adapt the presentation of evidence and influencing strategies to the changing context, and (4) embrace trial and error. The supply of evidence is one important but insufficient part of this story.
\end{abstract}

\footnotetext{
${ }^{1}$ Senior Researcher Influencing, Global Research Team, Oxfam GB, Oxford, UK. ${ }^{2}$ Strategic Advisor, Oxfam GB, Oxford, UK. ${ }^{3}$ Head of Research, Oxfam GB, Oxford, UK. ${ }^{4}$ Senior Researcher, Oxfam GB, Oxford, UK. ${ }^{5}$ National Influencing Advisor, Oxfam GB, Oxford, UK. ${ }^{6}$ Professor of Politics and Public Policy, Division of History and Politics, University of Stirling, Stirling FK94LA, Scotland. Correspondence and requests for materials should be addressed to P.C. (email: p.a.cairney@stir.ac.uk)
} 


\section{Introduction}

cademic studies of the politics of evidence-based policymaking suggest that policymaking can never be 'evidence based' (Cairney, 2016). At best, it is evidence-informed and subject to three factors. First, it is difficult to generate agreement on how to define evidence (even if adopting our focus on research evidence) and distinguish between high and low quality or relevant research (Nutley et al. 2007). Second, the world contains too much information for any actor to process comprehensively. Policymakers, unable to process all information relevant to policy, use cognitive and organisational shortcuts to process enough evidence to make decisions (Cairney and Kwiatkowski, 2017). Third, they do so in a policymaking environment over which they have limited control. There is no orderly 'policy cycle' in which a small number of powerful policymakers in government can gather the best evidence of a problem, select the most evidence-based solution, and make sure it is implemented, delivered, and evaluated. Rather, policymaking takes place in an unpredictable environment with many policymakers and influencers interacting at many levels and types of government. Further, each policymaking 'venue' (an arena or organisation in which people come together to make and influence authoritative decisions) produces its own formal and informal rules, networks, and dominant ways to define policy problems or respond to socioeconomic conditions and events (Cairney and Weible, 2017). Thus, policymaking resembles a complex system from which outcomes 'emerge', and in which the role of evidence is unclear (Geyer and Cairney, 2015).

The absence of an orderly and predictable policy process means that, to encourage the use of research evidence in policymaking, researchers and advocates need to better understand how policymaking works and how to respond. In this article, we combine academic and practitioner accounts to (a) generate a broad understanding of the role of evidence use in complex policymaking systems, and (b) learn lessons from an organisation that advocates for the uptake of research evidence in that context.

First, we synthesise key elements of policy theories to draw general lessons, such as adapting to the cognitive shortcuts of policymakers and dynamics of policymaking environments (Heikkila and Cairney, 2017). Common recommendations include telling a simple and persuasive story rather than bombarding policymakers with evidence, and engaging for the long term to identify: the right time to act, the actors with whom to form coalitions, the 'rules of the game', and the language of policy debate (Cairney and Weible, 2017).

In the series of articles devoted to this topic ${ }^{1}$, scholars and practitioners have written about key aspects of the role of evidence in policy making, including how to influence government ministers (Andrews, 2017), tell stories for policy impact (Davidson, 2017; Jones and Crow, 2017), and assess the impact of evidence on policy (Boswell and Smith, 2017). In most cases, scholars are describing how researchers can use the literature to develop skills for direct engagement.

A better strategy may be to work with, or learn lessons from, other actors with more experience. For example, many organisations are experienced influencers, intermediaries or knowledge brokers, including well-organised interest groups. Therefore, we draw on NGO experience of real world policy influencing to provide a wider source of lessons for research evidence advocates. We present practical examples that explain how experienced actors have engaged with the policy process effectively and how new actors can learn from their experience.

We draw on the experience of influencers and campaigners in Oxfam Great Britain: the UK affiliate of Oxfam International, a major international NGO devoted to reducing global poverty, human suffering, injustice, and inequalities relating to gender and other factors. Oxfam and its partners have been effective at evidence-informed policy change, usually as part of wider alliances and networks. It uses evidence to influence policy and to understand how to do so more effectively, via evaluation and lesson-learning. The article presents exemplar case studies of successful policy influencing by Oxfam staff and partners to highlight five tactics and strategies that have contributed to effectiveness including:

1. Learning how a political system works to understand what need to change to address an identified problem, who has the power to achieve change, and how to achieve change.

2. Designing, framing, timing and adapting the presentation of evidence to the changing context to maximise its influence on target audiences.

3. Using additional insider or outsider strategies to influence policy and practice.

4. Embracing trial and error.

Five of six authors are involved in research for influencing and campaigns, undertaking wider contextual research and/or conducting training for staff and partners on the use of evidence for influencing. The paper is based primarily on the authors' reflections on several sources, including: a meta review of 24 independent, randomised, Effectiveness Reviews of Oxfam's and partners national and regional influencing initiatives, using fuzzyset Qualitative Comparative Analysis (Shephard et al. 2018); 32 papers submitted to an Oxfam conference on Evidence for Influencing held in the Netherlands on 23-24 ${ }^{\text {th }}$ October 2017; evaluations and internal learning workshops and reviews; Oxfam research and discussion papers; personal correspondence with campaigners and influencers within Oxfam; and the authors' own research and influencing experience. This paper provides an overall narrative to identify effective policy influencing. However, not all influencing initiatives succeed, so in the final section we discuss the importance of embracing trial and error. While we focus primarily on influencing strategies, we note that an organisation's also success depends on its actual and perceived trustworthiness and legitimacy. We therefore separate routine learning, based on continuous reflection on strategy, from fundamental learning, based on the need to respond to Oxfam and the sector's safeguarding crisis.

\section{Insights from academic policy studies}

Policy studies provide abstract insights. They can be applied to most contexts, but we need to make concrete sense of them in different ways for different cases. First, policymaking is never 'evidence based'. Indeed, there is no agreed or common definition of evidence, policy, and policymaking (Cairney, 2016). While some policymakers maintain a 'hierarchy' of evidence to which they will respond based on particular research methods (such as randomised control trials) many do not (Oliver and Pearce, 2017). Many policymakers have a more eclectic view of evidence quality and are more interested in its relevance to policy problems (Nutley et al. 2007; 2013; Kenny et al. 2017). Further, this calculation differs markedly across policy areas, professions, levels of government, and according to how policymakers describe problems, such as urgent and salient or largely solved bar some technical aspects of delivery (Cairney, 2016; Cairney 2018a). Therefore, advocates of research evidence need to look beyond their own assessment of 'the evidence' to find out how policymakers think about problems and decide what evidence is relevant to them.

Second, there is more information available than any individual or governing organisation could process. No policymaker 
can consider all evidence relevant to decisions. 'Bounded rationality' (Simon, 1976) plays a profound role, as policymakers do not have the cognitive ability to consider all issues for which they are responsible, prioritise their aims consistently, or anticipate all of the effects of their decisions. Instead, they combine cognitive shortcuts to prioritise and interpret a small number of problems while ignoring the rest (Cairney and Kwiatkowski, 2017; Baumgartner and Jones, 2009, 2015).

Advocates of research evidence can respond effectively by identifying how policymakers process evidence: the methods they use to-in effect-ignore most information to allow themselves to make timely decisions. Researchers often make the mistake of addressing this situation by trying to increase the supply of high quality research evidence in a highly crowded environment. Such evidence matters, but its framing and the receptivity of policymakers to its implications are as important as scientific assessments of its quality. Effective advocates of research evidence frame information because they know that demand for evidence relates primarily to the necessarily simplified ways in which policymakers interpret complicated problems (Cairney et al. 2016). Therefore, an understanding of how policymakers apply cognitive shortcuts to information on policy problems can help evidence advocates design simple and persuasive stories, linked to their evidence base, rather than bombarding policymakers with evidence in the hope that they have an infinite capacity to process information.

Third, policy studies describe the environment or context in which this action takes place (Heikkila and Cairney, 2017; Cairney and Weible, 2017; Baumgartner et al, 2009). Policy actors operate in a messy environment over which central government policymakers often have limited control:

- They share power with many other policymakers, and influencers such as interest groups, operating across many levels of government or in public, private, and third sector bodies delivering policy (Gaventa, 2006).

- Policymaking organisations deal with their limited ability to process information by developing rules, norms, and standard operating procedures to simplify action.

- Politicians delegate responsibility to civil servants and a range of other regulatory, standard-setting or delivery organisations who in turn seek information and advice from influencers such as interest groups. They form networks-or webs of influence-built on the trust that comes from regular exchanges of information (Braithwaite and Drahos, 2000; Maloney et al, 1994).

- Policymaking tends to be dominated by 'paradigms' or 'monopolies of understanding' that can endure for decades because actors simplify their world by not questioning wellestablished ways of thinking based on beliefs, values, and ideology (Baumgartner et al. 2009).

- Policymakers are subject to socioeconomic conditions (power relations, geographic, demographic, economic) and routine or unanticipated events (elections, crises), which influence their attention to problems, constrain (or enable) policy choices, and create windows of opportunities for evidence advocates (Kingdon, 1984).

The result is a context in which power is distributed unevenly and in which governments, other institutions, interest groups, networks, ideas, and socioeconomic conditions interact to generate-intended and unintended-policy outcomes. The literature, some of which is informed by NGO practice, suggests that advocates of research evidence for policy need to develop strategies to engage effectively in their policymaking environment, such as to:
- identify which policymaking 'venues' are making key decisions, and the rules of those venues (Cairney and Weible, 2017)

- focus on influencing one venue or engage in 'venue shopping' to seek more sympathetic audiences (Baumgartner and Jones, 2009)

- emulate how interest groups use an effective mix of 'insider' and 'outsider' lobbying or campaigning strategies (Maloney et al. 1994)

- identify with whom to form coalitions based on shared aims or beliefs (Weible et al. 2012)

- learn from 'policy entrepreneurs' about how to exploit 'windows of opportunity' for policy change (Kingdon. 1984; Herweg et al. 2017; Jones et al. 2016; Cairney and Jones. 2016; Cairney, 2018b)

However, such general advice can only take us so far. We need to learn more about how researchers and policy advocates remain flexible and adaptive enough to turn general knowledge of policymaking into effective influencing strategies relevant to the issue and context. Those interested in research aimed at building more inclusive and sustainable societies can usefully learn from experienced interest groups, such as Oxfam. Such groups can offer more grounded, tried and tested practical insights which help turn abstract advice into concrete lessons.

\section{How Oxfam uses evidence to promote radical changes to policy and policymaking}

Oxfam is an international NGO devoted to reducing global poverty and injustice by providing urgent humanitarian support, supporting long-term development projects, and 'influencing' to address the root causes of poverty. It invests a growing proportion of spending on the latter, aiming to rebalance power relations in favour of poor and marginalised groups, and helping overcome structural influences that underpin poverty and injustice. Influencing in Oxfam entails systematic efforts to address: visible power expressed through observable rules, laws and institutions and decision-making processes; more hidden forms of power exercised by informal decision-makers and 'influentials' who operate behind the scenes; and 'invisible power' expressed through cultural beliefs and social norms (Rowlands, 1997; Gaventa, 2006). Its influencing strategies may seek to: change the policies and practices of governments and private companies; influence attitudes, beliefs, norms and behaviours of the public and officials; support and strengthen the capacity of marginalised individuals, groups and movements to claim their rights and participate in policy decision-making; and/or pioneer and scale up innovative development solutions.

We describe how Oxfam and partners uses research evidence to influence the policies and practices of public and private sector decision makers. This work is based on evaluations and experience that show that evidence is a necessary but often insufficient means to influence government and company policy and practice. Policy does not change simply because unequivocal evidence exists to demonstrate that particular practices ease or exacerbate human suffering. Rather, policy change is facilitated or hindered by powerful actors and factors reproducing the rules and dominant ideologies of political systems. For example, while there is a growing consensus from economists across the political spectrum that extreme levels of inequality are wrong and harm the economy, evidence-based action to reduce inequality is blocked by elites. Evidence on its own is unlikely to foster change unless accompanied by effective campaigning, political mobilisation and other forms of influencing. 


\section{Table 1 Examplars of Oxfam's global evidence-informed campaigns}

\begin{tabular}{|c|c|c|c|}
\hline $\begin{array}{l}\text { Campaign/influencing } \\
\text { title }\end{array}$ & Key evidence/ indicator & Principle, aim and change objective & Core storyline or messages \\
\hline \multicolumn{4}{|c|}{ Even it Up campaign: Time to end extreme inequality (ongoing) } \\
\hline $\begin{array}{l}\text { How to tackle inequality in } \\
\text { Vietnam } \\
\text { GROW campaign to fix the }\end{array}$ & $\begin{array}{l}\text { In 2017, eight men owned the same wealth } \\
\text { as the poorest } 3.6 \text { billion people. } 2018 \text { saw } \\
\text { the biggest increase in billionaires in } \\
\text { history, one more every two days. This } \\
\text { huge increase could have ended global } \\
\text { extreme poverty seven times over. } \\
\text { Vietnam's economic inequality is growing. } \\
\text { Its } 210 \text { super-rich earn enough in one year } \\
\text { to lift } 3.2 \text { million people out of poverty. } \\
\text { The richest man in Vietnam earns more in } \\
\text { a day than the poorest Vietnamese earns } \\
\text { in } 10 \text { years } \\
\text { food system (ongoing) }\end{array}$ & $\begin{array}{l}\text { Aim: a fairer distribution of wealth to } \\
\text { reduce poverty } \\
\text { Change objective: Influence government } \\
\text { policy on tax, resource mobilisation, } \\
\text { minimum wage, gender wage gap, social } \\
\text { protection and improved governance }\end{array}$ & $\begin{array}{l}\text { Extreme levels of inequality crisis } \\
\text { constrain poverty reduction. The super- } \\
\text { rich in } 2018 \text { are fuelling the inequality } \\
\text { crisis by dodging taxes, driving down } \\
\text { wages, and using their power to } \\
\text { influence politics } \\
\text { Poverty has fallen in Vietnam but } \\
\text { growing economic inequality } \\
\text { exacerbates poverty and exclusion from } \\
\text { public services and political decision } \\
\text { making }\end{array}$ \\
\hline $\begin{array}{l}\text { Behind the Brands } \\
\text { (Hoffman, 2018) }\end{array}$ & $\begin{array}{l}\text { Scorecard of company practices relating to } \\
\text { transparency, human rights, land use, and } \\
\text { climate effects }\end{array}$ & $\begin{array}{l}\text { Aim: improve livelihoods of poor farmers } \\
\text { and reduce climate change } \\
\text { Change objective: change company policy } \\
\text { and practice and help consumers choose } \\
\text { food from an ethical supply chain } \\
\text { dicines }\end{array}$ & $\begin{array}{l}\text { The big food companies are getting rich } \\
\text { at the expense of poor farmers and the } \\
\text { environment }\end{array}$ \\
\hline $\begin{array}{l}\text { Fatal Side Effects: } \\
\text { Medicine Patents under } \\
\text { the Microscope (Bailey } \\
\text { et al, 2001) }\end{array}$ & $\begin{array}{l}\text { Evidence of prohibitive medicine costs, } \\
\text { linked to WTO rules and company } \\
\text { practices }\end{array}$ & $\begin{array}{l}\text { Aim: Improve health by increasing access } \\
\text { to vital life-saving medicines } \\
\text { Change objective: reform WTO rules and } \\
\text { company pricing practices }\end{array}$ & $\begin{array}{l}\text { WTO patent rules and company } \\
\text { business models price HIV/AIDS and } \\
\text { other vital health saving medicines out } \\
\text { of the reach of people in poverty }\end{array}$ \\
\hline
\end{tabular}

There are four interacting ways in which campaigners and researchers in Oxfam seek to use evidence to influence government and company policy and practice.

Understanding political systems: what needs to change, who can achieve change, and how. Maximising the impact of evidence is only possible by learning how the wider political system works. In Oxfam, initiatives seek to maximise policy impact by investing in analysis and research to understand the key dimensions of change in a political system: (a) what needs to change to address poverty and injustice; (b) who has the power to achieve the desired change (and who or what influences them); (c) how to achieve change; and (d) wider contextual influences and trends. Oxfam staff use this information to inform its influencing and research strategy and also translates it into a range of knowledgebased influencing outputs: campaign reports, policy briefing papers, and creative resources such as social media posts, videos, posters and exhibitions.

(a) What needs to change. Like other NGOs, Oxfam and partners use participatory analytical tools, such as problem and solution trees (ODI, 2009) or PESTLE (Political, Economic, Social, Technological, Legal and Environmental Analysis, to help analyse context and hence understand 'what' needs to change to address poverty and social injustice. These tools provide an initial understanding of possible consequences, causes of, and solutions to poverty related problems such as displacement, poor health services, or declining wages. Causes may relate to unequal power relations, attitudes and beliefs, policies and practices, norms and behaviours, institutional practices and/or socio-economic factors.

When government or company policy is an important driver of an identified problem, Oxfam staff may also conduct additional research or analysis to: provide further evidence of policy discourses, implementation and impacts; or investigate and test policy solutions or alternatives. Oxfam internal guidelines stipulate that both analysis and research integrate gender analysis.

Oxfam then uses this analysis and research about what needs to change to (a) identify policy influencing aims and change objectives and (b) inform campaign reports and briefing papers to persuade governments about the need to achieve change. The latter combine evidence with compelling human stories and visualisations of evidence to highlight why these issues matter. They are used, alongside other influencing strategies, as tools to get an issue further up a global or national policy agenda, to shift the terms of the debate, or change or better implement policies. Some exemplars of this way of working are summarised in Table 1.

Experience and evaluation suggest that this formula can work when combined with additional influencing strategies. For example, Oxfam research for the Behind the Brands campaign score card contributed to important changes in how global companies engage their supply chains (Sahan, 2016). The research for the Access to Medicines campaign from 2001 helped weaken the influence of the giant pharmaceutical companies over government policy and contributed-as part of a wider global campaign with allies-to major reductions in the prices of HIV/ AIDs medicines (Coe et al. 2011; Mayne, 2002).

Other recent examples include Oxfam's research showing that Unilever's factory in Vietnam fell well short of paying a living wage (Wilshaw et al. 2013). Unilever subsequently improved the quality of jobs in the factory, reviewed its compensation policies and practices globally, and made many commitments to tackle labour issues in its global supply chain (Wilshaw et al. 2016). Further, policies such as the Scottish Government's establishment of an Inequality Commissioner, business pledge, and modified performance framework followed Oxfam's Humankind Index (2013a, 2013b).

Careful research design can increase the impact of such research. One characteristic of Oxfam's approach is the way it combines secondary data and analysis of macro trends and policies, with primary and participatory research about their human impacts on people. Primary research may entail focus group discussions, key informant interviews and case studies and other methods that offer a way for listening to people's voices on their own terms. Its recent use of SenseMaker (Mager et al. 2018; Guijt, 2016), for example, captures thousands of people's perspectives in ways that add analytical depth to generic statistics and quantitative assessments of qualitative insights.

Oxfam's research also combines policy analysis and critique with policy recommendations or solutions. Internally, discussion 
is ongoing about the potential for increasing policy influence by providing more concrete and detailed proof of concept for recommended policy alternatives. For example, the GROW campaign helped shift the terms of debate on agricultural food chains, and contributed to positive policy gains for rural women and small producers in Brazil, Colombia, Guatemala, and Paraguay. An evaluation of GROW suggested that more detailed research on its policy proposals could have helped further strengthen outcomes (Watson, 2016). Oxfam's work on a more human economy seeks to build an evidence-informed case for policy alternatives (Hardoon, 2017).

(b) Who has the power to achieve the desired change?. Power relations-whether visible, hidden or invisible (VeneKlasen and Miller, 2002; IDS 2010)-shape the potential for change in political, social or economic systems. To influence policy, strategies may need to target several audiences, including: visible and formal decision makers, such as MPs or people on government committees; hidden and informal influencers operating behind the scenes, such as corporate lobbyists or influential individuals; and, invisible cultural beliefs, social norms, and behaviours that constrain policy change or implementation, such as through broader media efforts.

All new Oxfam campaign or policy positions are expected to begin with a power analysis with relevant stakeholders to assess: (1) what kind of power dynamics are at play in any change process, (2) who has what kind of power to support the desired change, (3) who and what influences them, and (4) who supports or blocks change. Power analysis informs research design, including the kind of evidence, narrative and methodology best suited to different potential audiences (Table 2).

It also informs wider influencing strategies by providing vital political intelligence about the position of different individuals and institutions within the system and the most effective mix of insider and outsider influencing strategies and tactics. These may involve using evidence to strengthen the arguments of advocates or weaken those of opponents, enroling influential allies to support policy requests, naming and shaming the powerful through the media, shifting public attitudes and beliefs and mobilising the public, or helping build pro-change coalitions.

Power analysis was important, for example, in informing the influencing strategy of the successful Arms Trade campaign, aimed at regulating the sale of conventional arms and ammunition. In this case, the analysis categorised governments by their relative support for the Treaty overall and their positions about

\begin{tabular}{|c|c|}
\hline Audience & Evidence they might respond to best \\
\hline Elected policymakers & $\begin{array}{l}\text { Big ideas. Compelling stories. Positive } \\
\text { visions }\end{array}$ \\
\hline Civil servants & $\begin{array}{l}\text { Objective, rigorous } \\
\text { Credible methodology } \\
\text { Data. Technical details }\end{array}$ \\
\hline Corporate executives & $\begin{array}{l}\text { Company-specific findings. Credible } \\
\text { methodology }\end{array}$ \\
\hline Communities & $\begin{array}{l}\text { Community-focused } \\
\text { Generated with their participation }\end{array}$ \\
\hline $\begin{array}{l}\text { Activists, Public attitudes and } \\
\text { beliefs }\end{array}$ & $\begin{array}{l}\text { Human face to the story } \\
\text { Killer facts-easy to remember } \\
\text { Clear impacts of policy }\end{array}$ \\
\hline Media & $\begin{array}{l}\text { Controversial, new } \\
\text { Human face to the story } \\
\text { Killer facts with numbers }\end{array}$ \\
\hline
\end{tabular}

Source: Oxfam's Research for Advocacy guideline (Oxfam, 2016) individual elements (e.g., human rights or sustainable development) and was regularly updated in spreadsheets colour coded into 'champions', 'progressive supporters', 'swing supporters', 'undecided', and 'sceptics' (Green and MacDonald 2015).

Increasingly, power analysis conducted by Oxfam staff looks beyond formal and visible expressions of power to identify traditional/customary, informal and invisible power (Rowlands, 2016). Several programmes-including WeCare-now identify and address invisible power by seeking to transform the cultural beliefs and norms that prevent women's full participation in economic and public life. However, while the acceptance, use and sophistication of power analysis is growing in Oxfam, the authors' own reflections suggest that some staff do not use or update it frequently enough. Rather, campaigners can sometimes default to formulaic influencing tactics, such as digital petitions and/or fail to identify informal influencers or hidden and invisible sources of power. Additionally, staff sometimes forget to factor Oxfam's power into the analysis.

If necessary, staff supplement power analysis with additional research about the positions or decision-making processes of target audiences. For example, Oxfam South Caucuses Country Programme used social network analysis to better understand the composition and workings of national networks working on food security and how to strengthen them (Kvintradze, 2016).

(c) Understanding how to achieve change. Effective influencing requires an understanding of how change might best be achieved in specific contexts and times: identifying what type, mix, timing and sequencing of evidence and other influencing tactics will most plausibly contribute to desired changes. Such judgements are informed by a mix of contextual analysis, power analysis, know-how accumulated from experience, and evaluations.

Increasingly Oxfam is also generating lessons from metareviews of its influencing initiatives with partners and allies. For example, it recently commissioned a review of its national and regional policy influencing initiatives (Shephard et al. 2018). The review used fuzzy-set Qualitative Comparative Analysis to analyse 24 of Oxfam's independent and randomised Effectiveness Reviews of national and regional influencing initiatives (which use process tracing to assess Oxfam's contribution to identified outcomes). It investigated 'what combination of strategies worked to change policy and expand civic space, and what role Oxfam played, in the different contexts where it works?'. The review defined Widening civic space as expanding political spaces within which civil society organisations and citizens can exert power and have their voices heard on policy topics and Changing policy as bringing about change in the programmes, policies, procedures or budgets of the government, public officials or politicians/parties at any level.

The review found that in 15 of 22 relevant cases (68\%), Oxfam and partners successfully helped widen civic space and strengthen civil society participation and voice in policy making processes. In 8 of 15 relevant cases (53\%) they successfully changed government policy on a range of issues from health, gender equality, climate change, land rights, and poverty. In the 13 relevant cases that sought to both expand space and change policy simultaneously, only one successfully changed policy without also having expanded space. In other words, in relevant cases, there was a strong link between widening civic space and encouraging policy change. The review also confirmed that insider influencing strategies - building relationships with policy makers, presenting evidence and engaging in dialogue - were a necessary but not sufficient condition for influencing policy. Successful initiatives combined insider strategies with: (a) capitalising on 'windows of opportunity', or (b) outsider strategies that use overt pressure via high profile media or public mobilisation (while recognising this 
may be risky or difficult in contexts with restricted civic space), alongside strategies to strengthen civil society.

Oxfam also seeks to learn from social science. Some of Oxfam's policy influencing initiatives are explicitly informed by social and political science theories. For example, the global Enough Campaign is testing the effectiveness of strategies to change social norms that underpin violence against women and girls. Oxfam Novib also used behavioural insights to help inform its influencing messages on Dutch government aid allocations (Vlastuin, 2017). A recent Oxfam discussion paper reviewed learning from theory and practice about how to influence the gender, health, hygiene and environmental behaviours and practices of the public and government officials, and drew out the practical implications for strategy design (Mayne et al. 2018).

(d) Understanding and monitoring wider contextual trends. There is a risk of spending too much time and energy looking inward and asking 'what we are going to do', to the neglect of understanding how the wider complex system enables or constrains opportunities for change. This is particularly true of global organisations responding to different contexts in different countries. To address that weakness, Oxfam sometimes conducts research into wider systemic factors and contextual trends to inform or counter-balance the assumptions that campaign staff might otherwise make about how to achieve change (Green, 2016).

For example, Oxfam's Enough campaign to End Violence Against Women and Girls conducts research about, and seeks to transform, social norms and behaviours that either directly affect the lives of poor and marginalised women and/or constrain the implementation of policies and laws by officials or the public. This includes, for example, social norms relating to the legitimisation of violence and racism against indigenous women in Guatemala; the acceptance of intimate partner violence in India; the restriction of women's mobility in Pakistan; and early forced marriage in Indonesia.

Other recent contextual research investigated the profound effects of the rise of right wing populism (Galasso et al. 2017), as well as the narrowing effect and implications of civic space in some countries (Binh et al. 2016). The report highlighted implications for Oxfam's framing and narratives and the need for Oxfam to invest more in strengthening civil society voice rather than its own direct advocacy.

Another recent piece of research by Oxfam on political systems in fragile and conflict affected states (Green, 2017) highlighted the importance of identifying and engaging with non-state actors and identity-based organisations whether regional, ethnic, religious. Achieving change in such contexts requires long term processes aimed at shifting values and norms.

Overall, these activities - examining the what, who, and how questions, and the wider context - demonstrate that maximising the impact of evidence requires learning how a political system works and who is powerful within it. It would be ineffective to focus narrowly on evidence supply when, for example, there is lack of clarity about the audience, how they process information, and which factors influence their decisions. Turning a 100-page report into a one-page briefing may improve communication but miss the point.

Designing, framing, and timing evidence. One of the least effective ways to use research for influence is to write a paper and then ask 'right, who do I send it to?'. Anticipating the demand for evidence and influencing such demand presents an essential opportunity. Good practice initiatives in Oxfam try to increase research uptake and impact by integrating it with wider influencing strategies (see section 3 below), involving relevant stakeholders upstream in the research process, and carefully framing, communicating, and timing the release of research.

(a) Involving target audiences in the research process. Engaging stakeholders-whether partners, local communities, other allies, or target audiences-in research processes can increase the relevance, influence and impact of research, especially when they have been identified through a power analysis as key supporters or blockers of change. Oxfam requires all campaigns to adhere to an agreed set of program standards to build accountability and meaningful stakeholder participation into their design, implementation and review. Staff may establish reference groups - of partners, experts and staff - to guide the design, interpretation, and use of research. They may consult allies on policy positions. For example, in the run up to the G20 meetings in Turkey in 2015, Oxfam brought together civil society representatives from over 90 countries via online and offline platforms to discuss policy issues in relation to inequality, climate change, gender and governance. They may commission or involve academics to help strengthen the credibility and influence of research evidence. For example, Oxfam's UK Poverty Policy Advisory Group is an external expertise (academic and parliamentary) and scrutiny mechanism to ensure a convincing evidence base for advocacy work.

Staff and partners may also engage government and private companies in the research process. To enhance ownership by the national government and increase their confidence in the data, Oxfam in Nigeria used data from the national bureau of statistics and the Federal Inland Revenue in the preparation of its country inequality report (Mayah, 2017). It also involved the Ministry of Budget and Planning, including a Minister, in the unveiling and launch of the report. The national parliament called for a joint sitting on measures to address inequality barely 3 weeks after the launch. Oxfam and the Vietnamese government are discussing potential cooperation on measuring SDG 10, such as developing indicators to measure inequality which could offer a useful influencing opportunity. Critical engagement with food companies was important to the success of Behind the Brands (Sahan, 2016). Oxfam staff gave companies the opportunity to feedback on Oxfam's indicators for the score card. While not all company suggestions were taken up, the process enabled meaningful dialogue with them and experts on the extent to which their suggestions were relevant to all companies and/or could be verified with publicly available information. This dialogue helped identify some leading company practices that initial research had overlooked. It also increased company engagement with the campaign, as they could see that some indicators were shaped by the areas in which they demonstrated leadership. Engagement improved the quality of the scorecard and fostered relationships between Oxfam and the companies that would help shape progress, rather than alienating companies and prompting defensive responses.

(b) Framing and communicating research. Oxfam combines evidence with reasoned argument, strategic framing, and appeals to values, compassion and enlightened self-interest, to increase the salience and influence of research to its target audiences. Oxfam GB's Market Insights team conducts regular audience research (tracking surveys and focus groups) into how the public, key supporters and decision-makers view Oxfam's core campaign issues, which is in turn used to inform its communication and influencing messages and strategies. Where needed, this is supplemented by additional research. For example, the findings from a recent ten-country survey by Oxfam showed that informing people: (a) about the overall level of inequality and lack of social 
mobility, and (b) where they are situated in the income distribution, can increase support for certain types of government action (Hoy and Mager 2017).

One of the various framing tactics Oxfam uses to increase the influence of its research on target audiences is to humanise complex issues. Its research for the Arms Trade campaign is a powerful example (Hillier and Wood, 2003). The inclusion of survivors in campaign communications, UN delegations, regional meetings and gatherings meant that the campaign was able to stay focused on the ultimate humanitarian aim of the treaty, and ensure that those most affected by the issues had a say in the policy direction of the campaign (Green, 2016). Oxfam policy staff wrote the first NGO paper on tax havens in June 2002 which, by reframing tax as a development problem depriving developing countries of funding for health and education, catalysed the formation of the Global Tax Justice network and global campaigns on tax avoidance (Kimmis and Mayne, 2000). Oxfam also seeks to frame communication messages to appeal to the values of its core audiences and/or activate pro-social or environmental values in others (Crompton, 2010). For example, Oxfam GB is carrying out research to better understand and appeal to the concerns and values of its public audiences in relation to refugees. The effectiveness of such value-based framing has been demonstrated in campaigns on same-sex partnership in Ireland and US.

Second, the simple presentation of a few powerful but targeted facts can focus an audience on a profoundly critical issue. In recent years, Oxfam's 'killer facts' (Table 1) about extreme and worsening global wealth inequality have become an institution at the annual World Economic Forum gathering in Davos. In 2014, initial research calculated that the 85 richest individuals in the world had the same wealth as the poorest half of the world's population, 3.5 billion people (Fuentes-Nieves and Galasso, 2014). The ensuing media furore was startling and raised important issues on timing (a similar juxtaposition the previous year sank without trace) and framing. Subsequent annual updates of the statistics received similar levels of attention. Oxfam's global inequality 'killer fact' has since been repeated in speeches by political leaders, including former US President Obama, and it has helped frame inequality debates on its severity, urgency and global relevance.

Third, visualisations help increase the accessibility of evidence. Oxfam's 'doughnut' imagery encapsulates the challenges facing humanity to meet the needs of its population without exceeding the nine planetary boundaries (Raworth, 2012). This concept has gained widespread traction and prompted the author to develop a broader and acclaimed critique of the discipline of economics (Raworth, 2017).

Fourth, the messenger can be as important as the message. Oxfam works with and works with a range of influential people from civil society leaders to experts, thought leaders, and celebrities - to help communicate its research findings and policy asks. It also enrols external voices to support is influencing efforts. For example, at the 2016 World Economic Forum, Oxfam delivered a letter signed by 300 of the world's leading economists. It warned global leaders that tax havens cannot be economically justified as they undermine countries' abilities to collect taxes, with poor countries proportionally the biggest losers. The letter helped open up space for Oxfam and partners' influencing in several lower income countries and helped reinvigorate the call for more multilateral action on tax havens.

(c) Timing and adapting the presentation of evidence to changing contexts. Evidence is more likely to influence policymakers when presented to them during 'windows of opportunity', when they are motivated to pay attention to and solve a problem. Such windows may arise from critical junctures, such as regime change, to more subtle shifts, such as changes in public mood or media narratives. They may occur suddenly or unpredictably, requiring the capacity to detect and respond quickly. In these circumstances, there is rarely enough time to produce new research or work on novel solutions. Rather, Oxfam may repackage existing research to fit with the new policy framing and focus on getting evidence into the right hands at the right time. This approach resembles Kindgon's (1984) 'policy entrepreneurs' and involves finding the right time to present solutions to a policymaker with a motive and opportunity to act (Cairney, 2018b). Policymakers in the middle of a political change or crisis, and who are seeking advice, are also far likelier to pick up the phone to researchers they already know than to make new contacts or start reading unsolicited reports. Research advocates and policy influencers therefore need to invest in building links and relationships with decision makers in advance of such opportunities.

Most of Oxfam's global campaigns start with a major piece of foundational research and campaign report which lays out basic analysis and policy recommendations which may then be followed by shorter briefings and/or media releases framed and timed to coincide with changing events and windows of opportunity. For instance, in the global Access to Medicines campaign, Oxfam's policy briefings shifted from their initial focus on the practices of specific pharmaceutical companies, to a court case taken out by major companies against Mandela's South African government's drug policy, to WTO patent rules, to patent rules in Bilateral and Regional Free Trade Agreements, among others. Such reports and briefings are used to directly influence policy via advocacy and to guide and substantiate the content of Oxfam's media, public campaigning and social media actions (Mayne, 2002).

The Robin Hood Tax campaign provides an effective example of the strategic use of a window of opportunity. In 1972, Nobel laureate economist James Tobin suggested introducing a small tax on all financial transactions between different currencies, to curb short-term speculation and raise money for good causes. The idea got nowhere until advocated by NGOs after the global financial crisis of 2008. Crushed by debt repayments, finance ministers sought new sources of revenue for their cash-strapped governments. The banks and currency traders who opposed the tax had suddenly become pariahs. A coalition of trade unions, church groups, and NGOs rebranded the Tobin Tax as the 'Robin Hood Tax' and waged public campaigns across Europe, backed up by rapid reaction research to rebut the claims invoked by opponents. By 2011 the European Commission had proposed a Europe-wide tax on financial transactions (although negotiations continue as of 2018, across only ten countries). Similarly, through good relationships with journalists, Oxfam was able to make use of the leaks of the Panama and Paradise papers. For example, it and allies used the release of the Panama papers to make tax avoidance a key issue on the agenda of the anti-Corruption Summit hosted by David Cameron in 2016. Another example is how an Oxfam-supported local NGO Fundación Jubileo took advantage of the election of Evo Morales, the approval of a new constitution, and the promotion of political participation and decentralisation (a window of opportunity shaped by previous civil society action), to influence the local government to pass a new law on social auditing in La Paz, Bolivia.

The type and presentation of research also needs to be tailored to the salience of a policy issue. Ideas may move from a fringe issue to public debate to a key policy issue. The type of research required to get something on the public agenda is different from research designed to influence specific pieces of legislation. Oxfam's experience is that early entry into framing debates, including establishing normative principles while issues are still 
new and malleable, can have more influence than detailed research and influencing once an issue has moved to specifics and positions have hardened. For example, in the early stages of the discussion on the need for poor countries to adapt to climate change, a 'back of an envelope' 2007 calculation by Oxfam put the overall sum required at $\$ 50 \mathrm{bn}$ per year, a figure which was picked up and developed as the issue proceeded.

Such experiences suggest that the way in which evidence is coproduced, framed, timed and presented can be as important as its substance. Research quality matters, but can only have an impact if enough powerful actors are motivated to read it and have opportunities to act on the implications.

Combining evidence with additional influencing strategies. Oxfam's experience shows that evidence is an important but rarely sufficient condition to achieve policy change. Maximising the influence of evidence on policy requires alliances of different actors using a combination of influencing strategies:

- 'insider' persuasion of policy makers by developing relations, providing evidence, lobby and dialogue; identifying, pioneering and presenting development or humanitarian solutions to problems; enrolment of expert or influential voices to support policy asks; convening and brokering between marginalised groups and target audiences.

- 'outsider' action, to create pressure on policy makers, including via public mobilisation, high profile media, working with allies.

- taking advantage of windows of opportunity.

- widening civic society space by strengthening civil society voice, supporting social movements or helping get marginalised voices or neglected issues on to the policy agenda.

- local, national and international level influencing.

Staff, partners and allies adapt the mix, timing and sequencing of these influencing strategies to specific contexts and events. For example, public campaigns and protests targeting national governments may not be possible in contexts of restricted civic space so staff may focus more on the long-term work of building social movements and alternatives.

Oxfam also routinely considers and varies its own role according to the issue or context. On some global issues, where it is seeking to shift the terms of debate such as inequality, it retains a direct, bold and public voice. In many Global South contexts, it plays a supportive behind the scenes role due to its desire to support and not supplant local civil society voice or because of government sovereignty concerns (Shephard et al. 2018). The recent safeguarding crisis intensified internal reflection about whether and when to speak 'as Oxfam' and/or to work in coalition behind the scenes. It also re-emphasised the importance of (1) walking the talk i.e., ensuring that our internal institutional practices are aligned with our external influencing goals; (2) solid evidence to underpin influencing initiatives linked to people's experiences of poverty and injustice and to counter challenge; and (3) ensuring that the framing of powerful public campaigning and media work, needed to hold powerful actors to account, focuses on their actions rather than stigmatising individuals and organisations, and allows for the possibility of improvement.

Embracing trial and error and wider reflection. Using evidence effectively for policy influencing requires trial and error. Many NGOs, including Oxfam, have developed creative ways to compensate for their limited research capacity and to maximise their limited resources. These include:
Good Narratives that turn evidence and research into messages that stick in the minds of decision makers and opinion formers. According to a senior UK Foreign Office official 'We're seeing more academics producing abstracts and executive summaries, but they are too often abstracts rather than elevator pitches. Senior officials may have only 30 seconds to get hooked (or not) on what you are trying to say.'

Agility and immediacy. NGOs are less tied down than academics driven by the timescales of academic funding and publication requirements. Civil society focus is often urgent, immediate, and in response to events. NGOs can move quickly and loudly, reaching as many people as possible with clear messages of change.

Incentives to engage. NGOs invest heavily in building relationships with decision makers. Relationships can greatly increase research impact, because policymakers often open up to new ideas when a crisis hits but remain most likely to contact people they know and trust. However, effective influencing may sometimes also require the use, or threat of, a 'big stick', as a last resort even though this may disrupt relationships in the short term (Braithwaite, 2004).

Learning from practice. Oxfam seeks to adapt its influencing positions, strategies and tactics in the light of reflection and experience. It aims for all major campaigns to conduct periodic 'Action Reviews' linked to the planning cycle, where stakeholders are brought together to monitor progress and adapt influencing positions, strategies and tactics in response to feedback and the changing context. It also encourages regular monitoring and conducts independent and randomised formal evaluations such as the 'effectiveness reviews' (Hutchings, 2014) and periodic organisational wide strategic reviews.

However, Oxfam is a big place, with no one size fits all approach about how to maximise influence of evidence on policy makers. Internally, debates include:

- What mix of specialist and grass roots expertise should Oxfam use in its influencing efforts?

- To what extent should Oxfam's influencing seek to stay relevant to the media and policymakers by cycling rapidly between topics or maintaining a consistent long term focus on key themes?

- To what extent should it focus research and influencing efforts on: (a) elucidating problems and bearing witness (b) changing the public terms of debate (c) putting neglected or marginalised issues on policy agendas and/or (d) identifying and promoting specific policy solutions?

- What is the most effective mix, timing and sequencing of evidence and influencing tactics to maximise policy impact in a range of different contexts?

- To what extent should Oxfam identify and advocate for generic policy solutions and process issues, or seek to support context specific solutions through local iteration and experimentation?

We have described what Oxfam regards as good practice, but it is not universally observed and there are still challenges and unanswered questions. Plenty of Oxfam activity fails to hit its mark because of poor power analysis, an unconvincing narrative, an inappropriate framing or format for the key audience or suboptimal mix and sequencing of influencing strategies and tactics. Therefore, advocates of evidence-informed policy, including Oxfam, need to reflect continuously on the evidence of their own success and failure. 
Although we have focused primarily on influencing strategies, an organisation's success also depends on its actual and perceived trustworthiness and legitimacy. This is in turn linked to its perceived or actual legitimacy, authority, accountability, competence, integrity (values and practice), independence and quality of relationships, among other things (Oxfam internal market insights surveys; Lukes, 2005; Ezekiel, 2005; Mayne and Coe, 2008). The importance of trust, both generally, and for influencing work, was strongly reinforced by the 2018 sector wide safeguarding crisis, triggered by media articles about sexual misconduct by several of Oxfam's humanitarian staff in postearthquake Haiti in 2011. The ensuing media and public debate negatively affected perceptions of Oxfam, although the impact varied considerably between different geographies, issues and audiences. It also intensified existing internal reflection about, and efforts to, address gender injustice and power imbalances within Oxfam's operations, and between Oxfam and partners, in particular in relation to the safety of 'beneficiaries'. Addressing these issues, alongside the strengthening of safeguarding policy and practice, and improving Oxfam's culture, ways of working and practices, are key aspects of Oxfam's 10 Point Plan ${ }^{2}$ which seeks to build and strengthen a 'culture of zero tolerance' towards harassment, abuse or exploitation within Oxfam and across the sector. Such measures build on Oxfam's existing accountability and transparency measures such as regular public reporting, feedback and complaints mechanisms, diversity and inclusion measures, and efforts to improving internal practices (Oxfam, 2016). Routine learning about strategy is likely to be ineffective without such fundamental reflection on Oxfam's overall role in the world.

\section{Conclusions}

The use of evidence for policy influencing has many ingredients: a robust evidence base, framing and persuasion, simple storytelling, building coalitions, learning the rules of the game in many different systems, the use of complementary influencing strategies, and a process of continuous reflection and change in light of experience and context.

Practical experiences, such as Oxfam's, show that effective policy influencing requires a wide understanding of the role of research evidence. This message can be gleaned from a summary of the many steps from evidence to impact, as follows. Take a value and evidence based stance to identify the need for change in policy and policymaking. Identify the actors with the power to change policy, and the actors able to influence policymakers. Understand which strategies help produce most change, focusing on specific institutions and wider contextual trends. Identify people affected by the research and your target audiences, and work with them throughout relevant stages of research planning and production. Learn how to frame your evidence and provide it to your audience at the right time, using powerful visuals and well-known messengers. Test and adapt insider, outsider and other influencing strategies in light of experience, using trial and error across political systems and over time. Stay agile, engage with policymakers readily and continuously, respond quickly to events, test and learn from your strategies, and be prepared to trade-off accurate but ineffective versus simplified and effective messages. In other words, by showing the scale of this task, we show that evidence alone will not come close to making the difference.

Received: 29 March 2018 Accepted: 17 September 2018

Published online: 09 October 2018

\section{Notes}

1 The Politics of Evidence-Based Policymaking https://www.nature.com/collections/ xhxktjgpjc/

2 https://www.oxfam.org/en/oxfams-commitment-stamping-out-sexual-harassmentand-abuse

\section{References}

Andrews L (2017) 'How can we demonstrate the public value of evidence-based policy making when government ministers declare that the people have had enough of experts'?'. Palgrave Commun 3:11. https://doi.org/10.1057/s41599017-0013-4

Bailey M, Mayne R, Smith M (2001) Fatal Side Effects: Patents under the microscope. Oxfam

Binh LQ, Nguyen Thi Thu N, Pham Quynh P, Pham Thanh T (2016) Benchmark Assessment of Civil Society Space in Vietnam. Hong Duc Publishing House, Vietnam

Baumgartner F, Jones B (2009) Agendas and Instability in American Politics, 1st and 2nd edn. Chicago University Press, Chicago

Baumgartner FR, Jones BD (2015) The Politics of Information: Problem Definition and the Course of Public Policy in America. University of Chicago Press, Chicago

Baumgartner FR, Breunig C, Green-Pedersen C, Jones BD, Mortensen PB, Nuytemans M, Walgrave S (2009) Punctuated Equilibrium in Comparative Perspective. Am J Pol Sci 53(3):603-620

Boswell C, Smith K (2017) Rethinking policy 'impact': Four models of researchpolicy relations. Palgrave Commun 3:44. https://doi.org/10.1057/s41599-0170042-z

Braithwaite (2004) Methods of Power for Development: Weapons of the Weak Weapons of the Strong, Michigan. J Int Law 26:297-330

Braithwaite J, Drahos P (2000) Global Business Regulation. Cambridge University Press, Cambridge

Cairney P (2016) The Politics of Evidence Based Policy Making. Palgrave Springer, London

Cairney P, Jones M (2016) Kingdon's Multiple Streams Approach: What Is the Empirical Impact of this Universal Theory? Policy Stud J 44(1):37-58

Cairney P, Kwiatkowski R (2017) How to communicate effectively with policymakers: combine insights from psychology and policy studies. Palgrave Commun 3:37. https://doi.org/10.1057/s41599-017-0046-8

Cairney P, Weible C (2017) The New Policy Sciences. Policy Sci 50(4):619-27

Cairney P (2018a) The UK Government's imaginative use of evidence. British Politics, https://doi.org/10.1057/s41293-017-0068-2

Cairney P (2018b) Three habits of successful policy entrepreneurs. Policy Polit 46 (2):199-217

Cairney P, Oliver K, Wellstead A (2016) To Bridge the Divide between Evidence and Policy: Reduce Ambiguity as Much as Uncertainty. Public Adm Rev 76 (3):399-402

Coe J, Smith J, Duckworth B, Tibbett S (2011) Access to Medicines Evaluation 2001-2011, Oxfam America Evaluation Report

Crompton T (2010) Common Cause: The Case for Working with our Values, Joint Agency Research Report, FOE, Oxfam, COIN, WWF, CPRE; WWF-UK

Davidson B (2017) Storytelling and evidence-based policy: Lessons from the grey literature. Palgrave Commun 3:17093. https://doi.org/10.1057/ palcomms.2017.93

Ezekiel Z (2005) Rebuilding Trust in Canadian organisations: Governance and corporate social responsibility. The Conference Board of Canada, Deloitte, Canada

Fuentes-Nieves and Galasso (2014) Working for the Few. Political capture and economic inequality, Oxfam International, https://www.oxfam.org/en/ research/working-few

Galasso N, Feroci G, Pfeifer K, Walsh M (2017) The rise of populism and its implicatinos for Development NGOs, Oxfam America, Research Backgrounder

Gaventa J (2006) Finding the spaces for Change: A Power. Anal, IDS Bull 37 (6):23-33

Geyer R, Cairney P (eds.) (2015) Handbook on Complexity and Public Policy. Edward Elgar, Cheltenham

Green D (2012) Creating killer facts and graphics, Oxfam GB. https:// policypractice.oxfam.org.uk/publications/creating-killer-facts-and-graphics253013

Green D, MacDonald A (2015) Power and Change: The Arms Trade Treaty, The Active Citizenship series, Oxfam International, http://oxfamilibrary. openrepository.com/oxfam/bitstream/10546/338471/1/cs-arms-tradetreaty160115-en.pdf

Green D (2016) How Change Happens. Oxford University Press and Oxfam, Oxford, http://how-change-happens.com/

Green D (2017) Theories of Change for Promoting Empowerment and Accountability in Fragile and Conflict-Affected Settings. Oxfam, Action for 
Empowerment and Accountability, IDS. IDS Working Paper, Vol. 2017 No 499

Guijt I (2016) Innovation in Evaluation: Using SenseMaker to assess the inclusion of smallholder farmers in modern markets. In: Bell S, Aggleton P eds Evaluation in Health and Social Development: Interpretive and ethnographic perspectives. Routledge, UK

Hardoon D (2017) An Economy for the 99\%. It's time to build a human economy that benefits everyone, not just the privileged few, Oxfam Briefing Paper, Oxfam

Hastie R, Hoffler H (2015) Typhoon Haiyan, Community research into the relocation of internally displaced people in the Philippines, Oxfam Case Study, Oxfam International

Heikkila T, Cairney P (2017) A Comparison of Theories of the Policy Process. In: Weible C (ed.) Theories of the Policy Process 4th edn. Westview Press, Chicago

Herweg N, Zahariadis N, Zohlnhöfer R (2017) The Multiple Streams Framework: Foundations, Refinements, and Empirical Applications. In: Weible C, Sabatier P (eds) Theories of the Policy Process, 4th edn. Westview Press, Chicago

Hillier D, Wood B (2003) Shattered Lives: The case for tough international arms control, Campaign Report, Oxfam International

Hoffman B (2013) Behind the Brands: Food Justice and the 'Big 10' food and beverage companies, Oxfambriefing paper https://policy-practice.oxfam.org. uk/publications/behind-the-brands-food-justice-and-the-big-10-food-andbeverage-companies-270393

Hoy C, Mager F (2017) Cross country evidence about perceptions of inequality and support for redistribution. AEA RCT Registry

Hutchings C (2014) Balancing Accountability and Learning: A review of Oxfam GB's global performance framework. J Dev Eff 6:4, Routledge

Jones MD, Holly LP, Jonathan JP, Nicole H, Amiel B, Holly LR, Nikolaos Z (2016) A River Runs Through It: A Multiple Streams Meta-Review. Policy Stud J 44 (1):13-36

Jones M, Crow D (2017) How can we use the 'science of stories' to produce persuasive scientific stories? Palgrave Commun 3:53. https://doi.org/10.1057/ s41599-017-0047-7

Kenny C, Rose DC, Hobbs A, Tyler C, Blackstock J (2017) The Role of Research in the UK Parliament Volume One. Houses of Parliament, London, UK

Kingdon J (1984) Agendas, Alternatives and Public Policies 1st and 2nd eds. Harper Collins, New York, NY, 1995

Kvintradze A (2016) Understanding Networks: The application of Social Network Analysis methodology in the South Caucasus context, MECIS case studies, Oxfam

Le Quang B, Nguyen Thi Thu N, Pham QP, Pham TT (undated) Benchmark Assessment of Civil Society Space in Vietnam. Hong Kong Publishing House

Lukes S (2005) Power: A Radical View. 2nd edn. Palgrave, London

Mayne R, Coe J (2008) The Right Ethos: Power and Change. NCVO, London

Mager F, Becca S, Guijt I (2018) How decent is decent work: using SenseMaker to understand workers' experiences, Oxfam Research report

Maloney W, Jordan G, McLaughlin A (1994) Interest Groups and Public Policy: The Insider/Outsider Model Revisited. J Public Policy 14(1):17-38

Mayah E (2017) Inequality in Nigeria: Exploring the Drivers, Oxfam International

Kimmis J, Mayne R (2000) Tax Havens: Releasing the Hidden Billions for poverty eradication, Oxfam International, https://policy-practice.oxfam.org.uk/ publications/taxhavens-releasing-the-hidden-billions-for-povertyeradication-114611

Mayne R (2002) The Global Campaign on Patents and Access to Medicines; anOxfam perspective. In: Drahos P, Mayne R Eds Global Intellectual Property Rights: Knowledge, Access and Development. Palgrave Macmillan, UK, p 244-258. (2002)

Mayne R, Kesmaecker-Wissing M, Mizniak J, Knight L (2018) Influencing Behaviours and Practices to Tackle Poverty and Injustice, Oxfam Discussion Paper, Oxfam

Nutley S, Walter I, Davies H (2007) Using evidence: how research can inform public services. The Policy Press, Bristol

Nutley S, Powell A, Davies H (2013) What counts as good evidence? Alliance for Useful Evidence, London

ODI (2009) Planning Tools: Problem Tree Analysis, Toolkits https:/www.odi.org/ publications/5258-problem-tree-analysis

Oliver K, Pearce W (2017) Three lessons from evidence-based medicine and policy. Palgrave Commun 3:43, https://www.nature.com/articles/s41599-017-0045-9

Oxfam (2013a) Oxfam Humankind Index: The new measure of Scotland's Prosperity, second results, Oxfam GB. https://policy-practice.oxfam.org.uk/ publications/oxfam-humankind-indexthe-new-measure-of-scotlandsprosperity-second-results- 293743

Oxfam (2013b) The Journey to Sustainable Food: A three year update on the Behind the Brands campaign, Oxfam. https://www.oxfam.org/sites/www. oxfam.org/files/file_attachments/bpjourney-to-sustainable-food-btb-190416en.pdf

Oxfam (2016) Oxfam Accountability Report 2015-16 https://accountablenow.org/ accountability-in-practice/accountability-reports/oxfam-international/
Oxfam (undated) Tax at the Anti-Corruption Summit (ACS) - Oxfam's priorities, Internal document

Raworth K (2012) A Safe and Just Space for Humanity: Can we live within the doughnut. Discussion Paper, Oxfam International. https://policy-practice oxfam.org.uk/publications/asafe-and-just-space-for-humanity-can-we-livewithin-the-doughnut-210490

Raworth K (2017) Doughnut Economics: Seven Ways to Think like a 21st-Century Economist, Penguin

Rowland J (1997) Questioning Empowerment. Oxfam. https://policypractice. oxfam.org.uk/publications/questioning-empowerment-working-withwomen-inhonduras-121185

Rowlands J (2016) Power in Practice: Bringing Understandings and Analysis of Power into Development Action in Oxfam. IDS Bull 47:No 5, (2016) http:// bulletin.ids.ac.uk/idsbo/article/view/2796/ONLINE\%20ARTICLE

Sahan E (2016) The Journey to Sustainable Food: A three year update on the Behind the Brands Campaign, Oxfam. https://www.oxfam.org/sites/www. oxfam.org/files/file_attachments/bp-journey-tosustainable-food-btb-190416-

Smith L (2016) Researching the Killer Fact that Highlighted Global Economic Inequality, Oxfam GB. https://policy-practice.oxfam.org.uk/publications/ researching-the-killer-fact-thathighlighted-global-economic-inequality620162

Shephard D, Meuer J, Ellersiek A, Rupietta C (2018) The Effectiveness of Oxfam's Policy Influencing: Meta-Review using fsQCA, Oxfam Evaluation Report, https://policy28practice.oxfam.org.uk/publications/influencing-policy-andcivic-space-a-meta-review-ofoxfams-policy-influence-cit-620462

Simon H (1976) Administrative Behavior, 3rd Edition. MacMillan, London

True JL, Jones BD, Baumgartner FR (2007) Punctuated Equilibrium Theory'. In: Sabatier P (ed.) Theories of the Policy Process 2nd Edition. Westview Press, Cambridge MA

VeneKlasen L, Miller V (2002) A new weave of power, people and politics; the action guide for advocacy and citizen participation. Stylus Publishing US or Practical Action Publishing, UK

Vlastuin J (2017) How we used behavioural insights for digital campaigning, Oxfam Views and Voices, Oxfam Influencing Blog, https://views-voices oxfam.org.uk/author/jacco-vlastuin

Watson G (2016) GROW campaign in Latin America evaluation 20115-2016, Oxfam, internal document

Weible CM, Heikkila T, Sabatier PA (2012) Understanding and influencing the policy process. Policy Sci 45(1):1-21

Wilshaw R, Unger L, Chi DQ, Thuy PT (2013) Labour Rights in Unilever's Supply Chain: from compliance to good practice. An Oxfam study of labour issues in Unilever's Vietnam operations and supply chain, Oxfam. https:// policypractice.oxfam.org.uk/publications/labour-rights-in-unilevers-supplychain-from-complianceto-good-practice-an-oxf-267532

Wilshaw R, Chi DQ, Fowler P, Thuy PT (2016) Labour Rights in Vietnam: Unilever's progress and systemic challenges, Oxfam Research Report, Oxfam. https://policypractice.oxfam.org.uk/publications/labour-rights-in-vietnamunilevers-progress-and-systemicchallenges-614926

\section{Additional information}

Competing interests: Five of the six authors are Oxfam staff. The authors declare no competing interests.

Reprints and permission information is available online at http://www.nature.com/ reprints

Publisher's note: Springer Nature remains neutral with regard to jurisdictional claims in published maps and institutional affiliations.

Open Access This article is licensed under a Creative Commons Attribution 4.0 International License, which permits use, sharing, adaptation, distribution and reproduction in any medium or format, as long as you give appropriate credit to the original author(s) and the source, provide a link to the Creative Commons license, and indicate if changes were made. The images or other third party material in this article are included in the article's Creative Commons license, unless indicated otherwise in a credit line to the material. If material is not included in the article's Creative Commons license and your intended use is not permitted by statutory regulation or exceeds the permitted use, you will need to obtain permission directly from the copyright holder. To view a copy of this license, visit http://creativecommons.org/ licenses/by/4.0/.

(c) The Author(s) 2018 